\title{
IMPLEMENTASI PEMBELAJARAN PENDIDIKAN AGAMA ISLAM
} BERBASIS INTERNET DI SMA NEGERI 1 PAMEKASAN

\author{
1Diki Zulkarnayan, ${ }^{2}$ Mohammad Thoha \\ 1'Institut Agama Islam Negeri Madura, ${ }^{2}$ Institut Agama Islam Negeri Madura

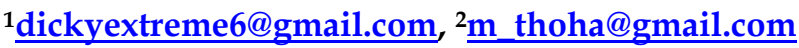

\section{Abstrak}

The implementation of Internet-Based Islamic Education Learning at SMAN 1 Pamekasan feels increasingly needed to be used as an alternative in fostering students' motivation and enthusiasm for learning, especially PAI learning. This study aims to examine teachers and students in innovating internetbased PAI learning, the obstacles experienced by teachers and students in implementing internet-based PAI learning, and also the implications of internetbased PAI learning at SMAN 1 Pamekasan. The focus of research in this study are: (1) How is the implementation of Internet-based PAI learning media at SMAN 1 Pamekasan? (2) What are the barriers to Internet-based PAI learning at SMAN 1 Pamekasan? (3) What is the solution to the obstacles to Internetbased PAI learning at SMAN 1 Pamekasan?

This study uses a qualitative approach which intends to understand the phenomenon of what is experienced by the research subject. Data collection techniques carried out by researchers are interviews, non-participant observations, and documentation of a number of related sources. Data analysis during the research and after the research took place using data reduction, data presentation, and data verification for field studies.

\section{ARTICLE HISTORY}

Received 31 Juli 2021

Revised 01 September 2021

Accepted 29 September 2021

\section{KEYWORDS}

Pembelajaran PAI, Berbasis Internet 
The results of the study indicate that: First, the implementation of internet-based PAI learning at SMAN 1 Pamekasan is quite adequate and is highly responded to by the principal, teachers, especially students. Although not $100 \%$ but with internet-based PAI learning, it is easy for teachers and students to carry out learning in class, which was originally boring to be fun and more efficient. Students who miss lessons can directly access learning by using the internet. Second, obstacles. Internet-based PAI learning at SMAN 1 Pamekasan is by providing training to PAI teachers regarding the implementation of internet-based learning, so that teachers who are less able to operate the internet can be helped by other PAI teachers. Third, student learning solutions and the use of internet-based PAI learning implementation at SMAN 1 Pamekasan, can be seen from the activeness of students in class and the results of student evaluations. To the principal of SMAN 1 Pamekasan for always providing support to teachers, especially PAI teachers related to internet media for the advancement of education at SMAN 1 Pamekasan. This support is by involving teachers in workshops or training on the implementation of internet-based PAI learning.

Kata Kunci: Pembelajaran PAI, Berbasis Internet

\section{PENDAHULUAN}

Dalam mewujudkan manusia yang berkualitas dan berpotensi dalam berbagai aspek kehidupan media memiliki peran utamayang sangat penting dalam menciptakan kemajuan bangsa dan negara. Sumber Daya Manusia (SDM) yang berkualitas menjadi salah satu faktor berkembang dan majunya suatu negara dapat dilihat dari bagaimana pendidikan mampu membentuk SDM tersebut.

Dalam proses belajar kemajuan ilmu pengetahuan dan teknologi semakin menghidupkan upaya pembaharuan dalam penggunaan hasil teknologi. ${ }^{1}$ Pemanfaatan teknologi dalam pembelajaran di lembaga-lembaga

\footnotetext{
${ }^{1}$ Azhar Arsyad, Media Pembelajaran Edisi Revisi (Jakarta: Raja Grafindo Persada, 2015), hlm. 2.
} 
pendidikan telah berkembang signifikan walaupun belum bisa diterapkan secara menyeluruh di semua lembaga pendidikan. Setidaknya ada dua kendala utama yang menghalangi penggunaan teknologi dalam pembelajaran. Pertama, sarana yang dibutuhkan terbatas misalnya komputer dan jaringan internet. Kedua, sumber daya manusia yang memiliki kompetensi memadai untuk mengoperasikan program dan aplikasi yang dibutuhkan terbatas.

Pembelajaran merupakan kegiatan yang dilakukan oleh guru secara terprogram dalam desain intructional (intructional design) untuk membuat siswa atau peserta didik belajar secara aktif (student active learning) yang menekankan penyediaan sumber belajar. Pada hakikatnya pembelajaran asalah kegiatan yang dilakukan secara sengaja yang mengkondisikan atau merangsang seseorang untuk bisa belajar dengan baik, agar mencapai tujuan pembelajaran yang telah dirumuskan. Oleh karena itu menurut Zayadi dalam buku kurikulum dan pembelajaran pendidikan agama islam yang ditulis Heri, kegiatan pembelajaran akan bermuara pada dua kegiatan utama, yaitu bagaimana orang melakukan tindakan perubahan tingkah laku melalui kegitan belajar dan kedua yaitu bagaimana orang melakukan tindakan penyampaian ilmu pengetahuan melalui kegiatan mengajar. ${ }^{2}$

Proses pendidikan merupakan inti dari pembelajaran. Di dalamnya timbul hubungan antara berbagai komponen, yaitu guru, siswa dan materi pelajaran atau sumber belajar. Media pembelajaran sering digunakan sebagai penyampaian perantara guru dalam menyampaikan materi pembelajaran. Sehingga memudahkan siswa dalam memahami suatu proses pembelajaran. ${ }^{3}$

Sudah kita ketahui bahwa peran teknologi dalam proses pembelajaran dan pengembangan ilmu pengetahuan sangat penting. Kemajuan teknologi tidak bisa dihindari dan kita tidak bisa menutup mata akan pentingnya penerapan teknologi dalam proses pembelajaran dalam rangka meningkatkan mutu

\footnotetext{
2 Ibid., hlm. 109.

${ }^{3}$ Zaiful Rosyid dkk, Ragam Media Pembelajaran Visual, Audio Visual, Interactive Video, Power Point, E-Learnig (Malang; Literasi Nusantara Abadi, 2020), hlm. 4.
} 
pembelajaran. Guru mempertimbangkan strategi dalam mengajar saat materi pembelajaran berlangsung.

Ada tiga bagian tujuan belajar, yaitu aspek kognitif, afektif, dan psikomotorik, yang mana harus diperoleh pada proses pembelajaran. Kognitif dilihat dari pemahaman dalam suatu pelajaran. Afektif dilihat dari pemahaman pada sikap siswa untuk lebih dapat merasakan simpati dan empati ketika melihat sebuah peristiwa secara langsung. Dan psikomotorik siswa dapat diukur dengan cara mengkreasi atau menirukan materi yang telah diajarkan ( keterampilan). Pada pembelajaran Pendidikan Agama Islam sampai saat ini masih bercorak menghafal, monoton, dan lebih mengutamakan pengkayaan materi. Dengan adanya kemajuan teknologi ini sangat membantu pembelajaran yang menurut siswa membosankan akan lebih menyenangkan terutama dalam memotivasi siswa. Kenyataan yang sering terjadi pada saat ini adalah ada banyak aplikasi digunakan dalam proses pembelajaran adalah internet dengan berbagai fasilitas dan bentuk aplikasinya.

SMA Negeri 1 Pamekasan ini upaya para guru untuk mencapai suatu tujuan pendidikan dengan cara memanfaatkan kemajuan teknologi informasi dan komunikasi. SMA Negeri 1 Pamekasan merupakan sekolah tingkat menengah atas yang sangat populer dan dikenal sebagai sekolah unggulan di kabupaten Pamekasan. Hal tersebut terlihat dari sisi kedisiplinan dan prestasi yang telah diraih oleh para siswa dan siswi SMA Negeri 1 Pamekasan. SMA Negeri 1 Pamekasan juga memiliki sarana dan prasarana yang sangat menunjang pembelajaran siswa siswinya, selain guru- guru yang professional salah satu bentuk kemajuan sekolah ini yaitu pemanfaatan media pembelajaran berbasis Internet sebagai bentuk pengembangan pembelajaran pendidikan agama Islam di SMA Negeri 1 Pamekasan, sehingga siswa dan siswi mudah dalam mengakses materi pembelajaran secara cepat dan mudah, yang mana pembelajaran berbasis internet ini memang sudah diterapkan meskipun sebelum COVID'19.

Hubungannya dengan pendidikan Islam, penggunaan teknologi dalam belajar mengajar sangat dibutuhkan. Salah satu media pembelajaran pendidikan 
Islam yang berbasis internet. Namun untuk melaksanakan pembelajaran ini, tidak lepas dari tantangan dan hambatan. Akan tetapi pasti ada peluang dalam menaerapkan suatu sistem pendidikan yang baru. Oleh karena itu, dalam skripsi ini peneliti membahas tentang Implementasi Pembelajaran PAI Berbasis Internet di SMAN 1 Pamekasan.

\section{METODE}

Peneliti dalam penelitian ini menggunakan pendekatan kualitatif yang bermaksud untuk memahami fenomena tentang apa yang dialami oleh subjek penelitian misalnya perilaku, persepsi, motivasi, tindakan, dan lain-lain secara holistik, dan dengan cara deskripsi dalam bentuk kata-kata dan bahasa, pada suatu konteks khusus yang alamiah dan dengan menggunakan berbagai metode alamiah. ${ }^{4}$

Penelitian dilihat dari jenisnya termasuk jenis penelitian kualitatif deskriptif yang dimaksudkan untuk mengumpulkan informasi atau memberi gambaran yang jelas tentang fenomena atau keadaan yang ada, yaitu keadaan gejala menurut apa adanya pada saat penelitian dilakukan. ${ }^{5}$

Penelitian kualitatif deskriptif ini sebagai prosedur penelitian yang menghasilkan data deskriptif berupa kata-kata tertulis atau lisan dari komponen pelaku yang ada di SMAN 1 Pamekasan yang berkaitan dengan Implementasi pembelajaran PAI berbasis internet. Peneliti berupaya mempelajari dan mengkaji secara mendalam tentang pembelajaran berbasis internet dalam pengembangan pembelajaran PAI di SMAN 1 Pamekasan, dan faktor-faktor pendukung serta penghambat terlaksananya inovasi pembelajaran tersebut.

Sumber data menurut Lofland sebagaimana dikutip oleh Moleong bahwa sumber data utama dalam penelitian kualitatif adalah kata-kata dan tindakan, selebihnya yaitu data tambahan seperti dokumentasi dan lain-lain. ${ }^{6}$

\footnotetext{
${ }^{4}$ Lexy J. Moleong, Metodologi Penelitian Kualitatif (Bandung: Remaja Rosda Karya, 2010), hlm. 6.

${ }^{5}$ Mukhtar, Metode Praktis Penelitian Deskriptif Kualitatif (Jakarta: GP Press Group, 2013), hlm. 11.

${ }^{6}$ Moleong, Metodelogi Penelitian Kualitatif, hlm. 157.
} 
Jenis data dalam penelitian ini yaitu pernyataan-pernyataan yang disampaikan oleh subjek penelitian sesuai dengan seperangkat pertanyaan yang dikemukakan oleh peneliti dengan merujuk pada fokus penelitian yang ada sebagai pedoman. Sedangkan dokumentasi, bersifat sebagai penguat/pembuktian dari data yang diperoleh berdasarkan pernyataan subjek penelitian tersebut.

Jadi sumber data dalam penelitian ini yaitu manusia dan non manusia. Sumber data manusia yakni Kepala sekolah, guru pengajar PAI, dan siswa. Dan data tersebut dirumuskan dalam bentuk transkrip wawancara, catatan pengamatan lapangan. Sedangkan data dalam bentuk non manusia dilakukan dengan jalan analisis dokumentasi.

Teknik pengumpulan data yang digunakan dalam penelitian ini adalah wawancara, observasi, dan dokumentasi. Dalam penelitian ini, peneliti menggunakan wawancara tidak terstruktur. Wawancara ini digunakan untuk memperoleh data tentang Implementasi Pembelajaran PAI berbasis Internet di SMAN 1 Pamekasan, dan faktor-faktor pendukung dan penghambat terlaksananya pembelajaran tersebut.

Observasi yaitu tekhnik pengumpulan data yang dilakukan dengan cara pengamatan dan melengkapinya dengan format atau blanko pengamatan sebagai instrumen. ${ }^{7}$ Dalam penelitian ini, penulis menggunakan observasi non partisipan, Artinya peneliti disini sebagai pengamat penuh sebab peneliti tidak berhak untuk masuk wilayah pribadi subjek. Peneliti hanya meninjau dan mengamati implementasi pembelajaran PAI berbasis Internet di SMAN 1 Pamekasan.

Dokumentasi adalah data pendukung yang dikumpulkan sebagai penguatan data observasi dan wawancara. ${ }^{8}$ Dalam penelitian ini, teknik ini

\footnotetext{
7 Suharsimi Arikunto, Prosedur Penelitian Suatu Pendekatan Praktek (Jakarta: Rineka Cipta, 2013), hlm. 272.

${ }^{8}$ Mukhtar, Metode Praktis Penelitian, hlm. 119.
} 
digunakan untuk mengumpulkan data dalam bentuk dokumen yang terkait dengan profil sekolah, serta dokumen yang ada kaitannya dengan fokus penelitian.

\section{HASIL DAN PEMBAHASAN}

\section{Implementasi Pembelajaran PAI yang berbasis Internet di SMAN 1 Pamekasan}

Dari hasil penelitian yang telah dilakukan oleh peneliti di SMAN 1 Pamekasan menunjukkan bahwa SMAN 1 Pamekasan merupakan sekolah unggulan yang terkenal akan kedisiplinannya dan prestasi yang diraih siswa siswinya. Kemajuan SMAN 1 Pamekasan tidak lain karena usaha para guru dan kepala sekolah yang saling bekerjasama dalam mengembangkan pembelajaran mulai dari materi pembelajaran, media, sarana dan prasarana yang mendukung serta semangat guru dalam berinovasi demi tercapainya suatu tujuan pendidikan yang diharapkan bersama.

Seperti halnya penuturan kepala sekolah Moh Arifin, S. Pd, M.Pd:

Pembelajaran PAI berbasis Internet merupakan sebuah pembaharuan dalam pembelajaran. Penggunakan internet ini merupakan upaya guruguru untuk mencapai tujuan pendidikan. Terutama guru PAI, seperti yang kita ketahui bahwasannya mata pelajaran PAI sangat membosankan ketika guru hanya menggunakan metode ceramah dan hafalan saja. Terkadang ada siswa yang bicara sendiri dengan temannya, bahkan sampai tertidur didalam kelas. Dengan adanya inovasi pembelajaran ini, guru sangat terbantu dan siswa pun lebih mudah mengakses materi pembelajaran. Kurikulum 2013 merupakan salah satu pendukung inovasi pembelajaran dengan menggunakan internet, dimana dalam kurikulum ini semua guru harus bisa menggunkan dan mengaplikasikan media e-learning seperti internet, computer, proyektor. Peraturan ini bukan hanya untuk SMAN 1 Pamekasan saja, melainkan seluruh SMA harus sudah bisa mengimplementasikan internet dalam pembelajarannya sebagai salah satu bentuk inovasi pembelajaran. Dalam pengaplikasian pembelajaran berbasis IT pemerintahpun juga 
terlibat, kalau tidah salah sejak tahun 2009. Hal itu terbukti dengan adanya langkah-langkah yang dilakukan oleh pemerintah adalah pada saat itu. Pertama, merancang sistem jaringan yang mencangkup jaringan internet, yang menghubungkan sekolah-sekolah dengan pusat data dan aplikasi, serta jaringan intranet sebagai sarana dan media komunikasi dan informasi intern sekolah. Dalam penerapannya pemerintah sudah melakukan upaya dalam perluasan jaringan. Terbukti dalam hal ini SMAN 1 Pamekasan sudah memilki akses internet yang menghubungkan dengan berbagai server pendidikan dan server pusat. Kedua, merancang dan membuat aplikasi database, yang menyimpan dan mengolah data dan informasi persekolahan, manajemen persekolahan dan lain-lain. Setiap sekolah mempunyai data base dan pengolahan data serta manajement persekolahan. Pemerintah mengupayakan agar terpenuhinya data-data yang bersifat otonom sekolah, sehingga data tersebut dapat dikaji lagi oleh sekolah secara baik. Ketiga, merancang dan membuat aplikasi pembelajaran berbasis portal, web, multimedia interaktif dll. Pemanfaatan teknologi informasi tidak hanya sekedar mengaplikasikan suatu sistem yang ada, namun lebih kepada bagaimana mengolah aplikasi tersebut sehingga mampu diterapkan dan mampu memberikan kemudahan dalam melakukan proses pembelajaran, SMAN 1 Pamekasan telah memiliki portal website sekolah yang dijadikan portal berita dan wahana belajar bagi siswa dan berbagai apliksai seperti pembelajaran internet yang berbasis Schoology baik dalam pembelajaran maupun ulangan harian. Keempat, pengoptimalan TV edukasi sebagai sarana penunjangan peningkatan mutu pendidikan masih sangat minim dalam mengoptimalkan TV edukasi, karena dalam penerapannya di SMAN 1 Pamekasan masih ditemui kendala yaitu belum berjalannya program TV edukasi tersebut. Kelima, mengimplementasikan pemanfaatan TIK secara bertahap untuk memudahkan manajement pendidikan pada SMA dan sekaligus untuk mendukung proses pembelajaran di seluruh wilayah Indonesia. ${ }^{9}$

Guru memiliki peran penting dalam menentukan suatu mutu pendidikan yang berkualitas. Karena gurulah yang akan selalu berhadapan dengan siswa dalam proses pembelajaran berlangsung. Sehingga dapat

\footnotetext{
${ }^{9}$ Moh. Hasan Arifin, Kepala Sekolah SMA Negeri 1 Pamekasan, Wawancara Langsung (3 Januari 2021).
} 
menghasilkan siswa yang baik dalam akademis, skill (keahlian), kematangan emosional, dan moral serta spiritual. ${ }^{10}$

Bentuk usaha guru di SMAN 1 Pamekasan terutama guru PAI untuk mencapai tujuan pendidikan yaitu dengan memanfaatkan pembelajaran berbasis internet. Internet merupakan salah satu bentuk inovasi pembelajaran PAI dengan memanfaatkan perkembangan dan kemajuan teknologi informasi dan komunikasi. Kepala sekolah dan guru PAI bekerjasama dalam mengatasi permasalahan pembelajaran siswa di kelas. Permasalahan yang terjadi selama ini di SMA negeri maupun swasta yaitu siswa yang merasa bosan dan malas dalam mendengarkan materi pelajaran yang dijelaskan oleh guru PAI. Salah satu contoh ketika guru menjelaskan materi didepan kelas, siswa dibelakang sedang main hp ataupun bercanda dengan teman sebangkunya. Sehingga materi yang dijelaskan guru sulit untuk dipahami.

Pemanfaatan media internet sebagai pembelajaran diterapkan di SMAN 1 Pamekasan merupakan suatu yang digunakan dengan berbagai cara untuk mendukung dan meningkatkan proses pembelajaran. Terdapat berbagai media internet yang digunakan di SMAN 1 Pamekasan, mulai dari aplikasi komputer online, teknologi presentasi seperti aplikasi Microsoft PowerPoint atau proyektor, World Wide, Web, web-conference, materi multimedia seperti foto atau animasi, tools untuk menilai pekerjaan siswa, permainan, dan sebagainya.

\footnotetext{
${ }^{10}$ Kunandar, Guru Profesional Implementasi KTSP dan Sukses dalam Sertifikasi Guru, hlm. 40.
} 
Faktor yang mempengaruhi implementasi pembelajaran PAI di SMAN 1 Pamekasan yaitu guru, siswa, dan fasilitas. Ilmu pendidikan Islam menjelaskan salah satu syarat menjadi guru yaitu guru harus berilmu, karena guru akan menjadi panutan dan contoh bagi siswanya. Faktor kedua yang mempengaruhi implementasi pembelajaran PAI berbasis media internet yaitu siswa. Ketika siswa sudah merasa jenuh dengan cara penjelasan guru yang sangat membosankan, maka guru harus pandai menciptakan pembelajaran seperti di SMAN 1 Pamekasan yang menggunakan internet. Siswa menjadi salah satu faktor dari implementasi pembelajaran PAI karena sebagai obyek utama dalam pendidikan terutama dalam proses pembelajaran. Siswa akan menjadi faktor penentu tercapainya suatu tujuan belajar. ${ }^{11}$

Sebelum memilih menggunakan internet, guru terlebih dulu harus menguasai dunia internet sebelum diterapkan dalam proses pembelajaran. Dan juga mempersiapkan beberapa perangkat utamanya komputer dan semacamnya. Sehingga diperoleh hasil pembelajaran yang maksimal. ${ }^{12}$

Menurut Mukhtar dan Iskandar dalam bukunya yang berjudul Desain pembelajaran TIK, teerdapat banyak metode yang dapat digunakan, antara lain: diskusi, demonstrasi, problem solving, inkuiri, dan discoveri. ${ }^{13}$ Guru menyajikan topik, kemudian siswa diminta untuk mencari hal-hal yang berkaitan dengan topik tersebut di internet. Guru juga dapat memberikan

\footnotetext{
11 Sardiman, Interaksi \& Motivasi Belajar Mengajar ( Jakarta: Rajawali Pers, 2011), hlm. 111.

12 Mukhtar Iskandar, Desain Pembelajaran Berbasis TIK (Jakarta: Referensi, 2012), hlm. 328.

13 Ibid., hlm. 329.
} 
Diki Zulkarnayan dan Mohammad Thoha, Implementasi Pembelajaran

Pendidikan Agama Islam Berbasis Internet di SMA Negeri 1 Pamekasan

DOI: htts://doi.org/10.19105/rjpai.v2i2.4949

tugas lain sehingga siswa dihaeuskan untuk mengakes dari internet, contohnya yaitu guru menugaskan untyk menulis cerita kisah keteledanan Nabi dan Rasul, informasi atau cerita tersebut bisa dicari di internet.

\section{Hambatan Pembelajaran PAI berbasis Internet di SMAN 1 Pamekasan}

Implementasi pembelajaran PAI berbasis internetdi SMAN 1 Pamekasan memiliki manfaat yang besar dalam meningkatkan kualitas hasil belajar siswa. Guru dan kepala sekolah SMAN 1 Pamekasan telah menunjukkan keberhasilan dari pelaksanaan implementasi pembelajaran berbasis internet. Guru PAI telah membuktikan bahwasannya pembelajaran agama Islam tidak membosankan dan metode pembelajarannya bisa mengikuti perkembangan zaman. Akan tetapi dari beberapa keberhasilah guru dan kepala sekolah dalam melakukan inovasi pembelajaran berbasis media internet di SMAN 1 Pamekasan, pastinya terdapat hambatan-hambatan dalam pelaksanaannya. Salah satu hambatannya yaitu kurangnya pengetahuan guru yang senior tentang pengaplikasian internet.

Hambatan antara lain, ketersedian dan infrastruktur yang layak pada internet teresebut. Dalam kenyataannya tidak semua sekolah memiliki perangkat untuk menjalankan internet. Saat seorang pendidik menyampaikan pembelajaran melalui internet maka peserta didik harus menggunakan komputer dan jaringan internet untuk menerimannya namun tidak semua peserta didik memiliki perangkat tesebut di rumahnya. Peserta didik yang tidak memiliki mendapat hambatan dan harus pergi ke warnet (contohnya) untuk menggunakan internet tersebut dan itu menambah biaya pembelajaran. 
Hambatan lain dari peserta didik yang belum dapat mengoperasikan komputer begitu juga halnya pendidik. Tidak dapat pungkiri pada daerah tertentu tidak dapat menerapkan pembelajaran berbasis internet . Penggunaan internet tidak dapat diterapkan karena memang peserta didik yang belum mengetahui dan menguasai bagaimana mengoperasikan internet tersebut. Hal tersebut juga terjadi pada pendidik karena dulu belum ada internet saat mereka menempuh pendidikan. Sebagaimana penuturan Safrawi selaku guru PAI yaitu sebagai berikut:

Hambatan yang saya hadapi dalam pembelajaran PAI berbasis internet di SMAN 1 ini yaitu kurangnya pemahaman saya dalam mengaplikasikan laptop dan memanfaatkan internet. Sehingga terkadang saya masih perlu bantuan dan bimbingan dari guru PAI yang lain terkadang saya bertanya pada guru TI. Untungnya di SMAN 1 Pamekasan ini ada pelatihan komputer untuk para guru, sehingga saya bisa belajar tentang penggunaan internetini. Dalam pembelajaran keseharian saya mengusahakan menggunakan power point dalam setiap penjelasan. Terkadang saya tayangkan video pembelajaran yang berkaitan dengan materi pembelajaran PAI. Ketika ulangan harian disini menggunakan aplikasi schoology, jadi saya jika memasukkan soal ulangan, saya terkadang masih minta bantuan pada guru TI guru PAI yang lain. ${ }^{14}$

Wina Sanjaya dalam bukunya menuliskan beberapa hambatan yang terjadi di sekolah atau lembaga pendidikan tentang penggunaan media internet, diantaranya: 15

1. Budaya belajar siswa yang rendah.

2. Kemampuan dan kemauan membaca yang lemah

3. Masih banyak guru yang berpandangan mengajar sebatas menyampaikan materi pelajaran.

\footnotetext{
${ }^{14}$ Safrawi, Guru PAI SMAN 1 Pamekasan, Wawancara Langsung (10 Februari 2021).

${ }^{15}$ Wina Sanjaya, Media Komunikasi Pembelajaran (Jakarta: Prenada Media Group, 2012), hlm. 195.
} 
4. Masih banyak guru yang belum memahami dan dapat mengoprasikan komputer.

5. Banyaknya sekolah yang belum memiliki fasilitas komputer danlemahnya jaringan wifi.

\section{Solusi dari hambatan Pembelajaran PAI berbasis Internet di SMAN 1 Pamekasan}

Dari hasil penelian yang dilakukan penulis, pembelajaran berbasis internet yang digunakan dianggap belum berlangsung dengan baik dan maksimal apabila diterapkan pada sekolah yang sarana dan prasananya belum memadai. Pelaksanaan pembelajaran berbasis internet membutuhkan perencanaan dan perhatian khusus, terutama sarana prasarana yang digunakan, jaringan internet yang memadai, dan motivasi diri agar bisa mengikuti proses pembelajaran.

Permasalahan yang terjadi dalam pembelajaran berbasis internet diantaranya adalah belum meratanya akses jaringan internet, handpohone yang belum memadai, mahalnya biaya kuota, belum meratanya penguasaan iptek di kalangan pendidik atau guru, belum siapnya pelaksanaan proses belajar mengajar menggunakan metode pembelajaran berbasis internet, dan pendampingan orang tua yang mengalami kesulitan saat berlangsungnya pembelajaran berbasis internet.

Dalam mendukung pendidik dan tenaga pendidik peran kepala sekolah memiliki peranan penting dalam pelaksanaan pendidikan jarak jauh ini. Dengan adanya kebijakan pemberian pelatihan melalui webinar ataupun workshop tentang proses belajar mengajar bagi para pendidik dan tenaga 
kependidikan dapat meningkatkan kualitas lembaga pendidikan tersebut dalam memberikan layanan bagi peserta didik.

Kerja sama yang dilakukan antara pihak sekolah dengan pihak provider untuk peningkatan layanan internet di sekolah merupakan salah satu upaya pemecahan masalah tentang keterbatasanya sarana dan prasarana penunjang ilmu pengetahuan dan teknologi di sekolah untuk peningkatan mutu. Pentingnya peran kepala sekolah dalam menjalin kerja sama dengan provider dalam proses pemberian subsidi kuota yang hali ini menjadi penolong dan pemberi bantuan yang dapat mengurangi beban orang tua dan siswa.

\section{PENUTUP}

\section{Kesimpulan}

Dari hasil penelitian diatas, penulis dapat menyimpulkan:

1. Pembelajaran PAI berbasis Internet merupakan sebuah pembaharuan dalam pembelajaran. Penggunakan internet ini merupakan upaya guru-guru untuk mencapai tujuan pendidikan. Terutama guru PAI, seperti yang kita ketahui bahwasannya mata pelajaran PAI sangat membosankan ketika guru hanya menggunakan metode ceramah dan hafalan saja. Terkadang ada siswa yang bicara sendiri dengan temannya, bahkan sampai tertidur didalam kelas. Implementasi pembelajaran PAI berbasis internet di SMAN 1 Pamekasan sangat perlu sebagaimana kondisi saat ini (masa pandemi) dengan keterbatasan ruang gerak yang diatur oleh pemerintah, situasi sekarang perlu menggunakan internet dalam pembelajaran dan penugasan. 
Sebelum adanya masa pandemi SMAN 1 Pamekasan sudah melakukan pembelajaran berbasis internet tetapi hanya terbatas pada kegiatan ulangan saja, serta tugas-tugas yang perlu diselesaikan dan butuh refrensi yang berbeda. Secara umum sebelum adanya masa pandemi pemebelajaran PAI lebih banyak dengan tatap muka dibandingkan dengan pembelajaran yang menggunakan internet, dan semenjak masa pandemi guru PAI sangat mengapresiasi adanya pemebelajaran PAI berbasis Internet di SMAN 1 Pamekasan dikarenakan dengan pemanfaatan internet dalam segala aspeknya terutama dalam pembelajaran.

2. Hambatan pembelajaran PAI berbasis internet di SMAN 1 Pamekasan disini ada beberapa hal, diantaranya tidak semua siswa ketika jam pembelajaran dimulai bisa masuk, dikarenakan jaringan kurang memadai. Tidak hanya itu, terkadang hambatan itu datang dari guru yang sudah dikatakan tua sehingga kurang paham terhadap internet. Dalam hambatan yang paling dirasakan oleh siswa dan guru SMAN 1 Pamekasan ini yaitu jaringan internet. Meskipun sudah terpasang 2 jaringan wifi tetap kurang dan jaringannya lemah. Hal ini disebabkan banyaknya pengguna yang tersambung ke wifi dan mengakibatkan jaringan menjadi lemah. Terkadang lemahnya jaringan internet karena gangguan dari Telkom dan yang paling menghambat yaitu ketika terjadi pemadaman listrik secara serentak. Jadi, inti dari hambatan tersebut ialah fasilitas yang dimiliki oleh siswa itu sendiri. 
3. Solusi dari hambatan implementasi pembelajaran PAI berbasis internet di SMAN 1 Pamekasan yaitu dengan memberikan pelatihan kepada guru-guru yang belum bisa menggunakan jaringan internet, kemudian ada penambahan jaringan wifi supaya lebih mudah dalam mengakses pembelajaran dari internet.

\section{Saran}

Berdasarkan dari permasalahan tentang Implementasi pembelajaran PAI berbasis internet di SMAN 1 Pamekasan, maka disarankan:

1. Kepada kepala sekolah SMAN 1 Pamekasan untuk selalu memberi dukungan terhadap guru terutama guru PAI dalam berinovasi demi kemajuan pendidikan di SMAN 1 Pamekasan. Dukungan tersebut dengan mengikut sertakan guru dalam worksop ataupun pelatihan tentang inovasi pembelajaran dengan berbasis internet.

2. Kepada semua guru terutama guru PAI SMAN 1 Pamekasan, hendaknya lebih meningkatkan wawasan dan pengetahuannya tentang implementasi pembelejaran PAI berbasis internet. Karena pembelajaran tidak harus menonton dengan metode yang membosankan, guru harus pandai memotivasi peserta didiknya dalam pembelajaran dikelas.

3. Pembelajaran PAI berbasis internet dengan aplikasi schoology layak digunakan dan dimanfaatkan oleh guru dan peserta didik karena media internet ini sangat menguntungkan dan mempermudah siswa dalam pembelajaran. Akan tetapi ketika peserta didik menggunakan internet harus 
Diki Zulkarnayan dan Mohammad Thoha, Implementasi Pembelajaran

Pendidikan Agama Islam Berbasis Internet di SMA Negeri 1 Pamekasan

DOI: htts://doi.org/10.19105/rjpai.v2i2.4949

dengan pantauan guru dan orang tua. Karena di internet terdapat situs yang tidak mendidika peserta didik, jadi ketika menggunakan media internet harus dengan pantauan dari guru maupun orang tua ketika dirumah.

4. Peneliti hanya mengkaji sebagian kecil dari Implementasi Pembelajaran PAI berbasis Internet di SMAN 1 Pamekasan. Disamping karena keterbatasan peneliti serta kekurangan kemampuan dalam aspek analisis, sehingga penelitian ini lebih lanjut mengenai bentuk pemaparan Inovasi pembelajaran berbasis e-learning baik dari aspek kurikulum, pendidik, maupun lingkungan peserta didik di sekolah maupun diluar sekolah. Dengan demikian masih terdapay ruang yang sangat terbuka untuk peneliti lain yang berminat meneliti masalah serupa.

\section{DAFTAR RUJUKAN}

Arikunto, Suharsimi. Prosedur Penelitian Suatu Pendekatan Praktek. Jakarta: Rineka Cipta, 2013.

Arsyad, Azhar. Media Pembelajaran Edisi Revisi. Jakarta: Raja Grafindo Persada, 2015.

Iskandar, Mukhtar. Desain Pembelajaran berbasis TIK. Jakarta: Referensi; 2012.

Kunandar, Guru Profesional implementasi KTSP dan Sukses dalam Sertifikasi Guru.

Moleong, Lexy J. Metodologi Penelitian Kualitatif. Bandung: Remaja Rosda Karya, 2010.

Mukhtar, Metode Praktis Penelitian Deskriptif Kualitatif. Jakarta: GP Press Group, 2013.

Rosyid, Zaiful, dkk. Ragam Media Pembelajaran Visual, Audio Visual, Interactive Video, Power Point, E-Learnig. Malang; Literasi Nusantara Abadi, 2020. 
Diki Zulkarnayan dan Mohammad Thoha, Implementasi Pembelajaran

Pendidikan Agama Islam Berbasis Internet di SMA Negeri 1 Pamekasan

Sanjaya, Wina. Media Komunikasi Pembelajaran. Jakarta: Prenada Media Group, 2012.

Sardiman, Interaksi \& Motivasi Belajar Mengajar. Jakarta: Rajawali Pers, 2011. 